\title{
Some of the Food Color Additives Are Potent Inhibitors of Human Protein Tyrosine Phosphatases
}

\author{
Suja Shrestha, Bharat Raj Bhattarai, Keun-Hyeung Lee, and Hyeongjin Cho \\ Department of Chemistry and Institute of Molectular Cell Biology, Inha University, Incheon 402-751, Korea \\ "E-mail:khlee@inha.ackr; hoho@imha.ackr. \\ Received Mav 6, 2006
}

\begin{abstract}
Synthetic color additives approved for general food use are sixteen in European Union, seven in U. S. $\Lambda$. and twelve in Japan. Twelve food dyes were examined for their inhibitory potency against human protein tyrosine phosphatases (PTPases). IIalf of the food colorants inhibited PTPases significantly and three of them were potent inhibitors with low micromolar $I_{50}$ values. $\Lambda$ lso examined were the synthetic dyes structurally similar but not allowed in food. Some of them were potent inhibitors of PTPases. Considering the importance of PTPases in cellular signal transduction, inhibition of PTPases by food colorants might cause harmful effects in human health.
\end{abstract}

Key Words : Food color additive, Certified color, Dye, Protein tyrosine phosphatase, Enzyme inhibitor

\section{Introduction}

Color additives are used in a wide variety of foods such as beverages, dairy products, cereals, bakery goods, snack foods and ice creams. The use of the additives is strictly controlled in most of the countries by food sanitation laws. Colors permitted for use in foods are generally classified as certified or exempt from certification.' Certified colors are man-made and there are seven certified colors approved for general food use in the United States and twelve colors approved in Japan (Table 1). In European Union (EU), sixteen synthetic colors are approved and eight of them are listed in Table 1. Color additives that are exempt from certification include pigments derived from natural sources such as vegetables, minerals or animals.

Although food colors are carefully regulated to ensure their safety, not all colors are harmless and their adverse side effects have been reported. For example, anaphylaxis, hyper- tension, hypotension and teratogenicity were reported for Indigocarmine. ${ }^{2-5}$ Anaphylaxis due to carmine allergy was also reported. ${ }^{6}$ Rose Bengal is known to affect $\operatorname{IgE}$ production. ${ }^{7}$ This dye and other artificial food colors may be cytotoxic to hepatocytes. ${ }^{89}$ Fast Green FCF inhibits synaptic activity in rat hippocampal interneurons and Tartrazine stimulates mitogenic process. ${ }^{10,11}$ Azo dyes such as Amaranth, Allura Red and New Coccine induced colon DNA damage in rodents. ${ }^{12}$ A few food colors in combination with other additives produced adverse effects in platelet function. ${ }^{13}$ The relevance of food additives in the pathogenesis of atopic dermatitis was also suggested. ${ }^{14}$ The mechanism of these observations is largely unknown in most of the cases.

While studying the enzymology of protein tyrosine phosphatases (PTPases), we observed that some of the dyes behaved as potent inhibitors of PTPases. ${ }^{15.16}$ PTPases are a class of enzymes that hydrolyze the phosphate moiety from a phosphotyrosine residue of a protein thus regulating the

Table 1. Synthetic food colorants permitted by the Food Sanitation Laws of U. S. A. (1-7)', Japan (1-3, 4-12) and European Union (1-2, 4-9)

\begin{tabular}{|c|c|c|c|c|c|c|}
\hline Compds. & FDA name $^{b}$ & Japanese name & ENo." & Common name & CAS No. & $\mathrm{CINo}^{d}$ \\
\hline 1 & FD\&C Blue No. 1 & Food Blue No. 1 & E-133 & Brilliant blue FCF & $3844-45-9$ & 42090 \\
\hline 2 & FD\&C Blue No. 2 & Food Blue No. 2 & $\mathrm{E}-132$ & Indigotine & $860-22-0$ & 73015 \\
\hline 3 & FD\&C Green No. 3 & Food Green No. 3 & & Fast green FCF & $2353-45-9$ & 42053 \\
\hline 4 & FD\&C Red No. 3 & Food Red No. 3 & $\mathrm{E}-127$ & Erythrosine & $16423-68-0$ & 45430 \\
\hline 5 & FD\&C Red No. 40 & Food Red No. 40 & E-129 & Allura Red AC & $25956-17-6$ & 16035 \\
\hline 6 & FD\&C Yellow No. 5 & Food Yellow No. 4 & $\mathrm{E}-102$ & Tartrazine & $1934-21-0$ & 19140 \\
\hline 7 & FD\&C Yellow No. 6 & Food Yellow No. 5 & E-110 & Sunset Yellow FCF & $2783-94-0$ & 15985 \\
\hline 8 & D\&C Red No. 2 & Food Red No. 2 & E-123 & Amaranth & $915-67-3$ & 16185 \\
\hline 9 & & Food Red No. 102 & $\mathrm{E}-124$ & New Coccin & $2611-82-7$ & 16255 \\
\hline 10 & D\&C Red No. 28 & Food Red No. 104 & & Phloxine B & $18472-87-2$ & 45410 \\
\hline 11 & & Food Red No. 105 & & Rose Bengal & $632-69-9$ & 45440 \\
\hline 12 & & Food Red No. 106 & & Acid Red 52 & $3520-42-1$ & 45100 \\
\hline
\end{tabular}

"Among the nine certified colors approved for food use in U. S. A., Otange B and Cittus Red No.2 are restricted to specific uses and they are not listed in this table. 'Tn FD\&C and D\&C, capital letters represent food, drug and cosmetics, respectively. "Tn European Union, sixteen synthetic colors are approved and seven of them are listed in this Table. "CI No. abbreviates color index number. 
<smiles>CCN(Cc1cccc([N+](=O)[O-])c1)c1ccc(C(=C(c2ccccc2)c2cccc([O-])c2)c2ccc([N+](CC)(Cc3cccc([N+](=O)[O-])c3)Cc3cccc([N+](=O)[O-])c3)cc2)cc1</smiles><smiles>O=C(O)c1ccccc1C1c2cc(I)c(O)c(I)c2Oc2c(I)c(O)c(I)c(I)c21</smiles>

4. Erythrosine B

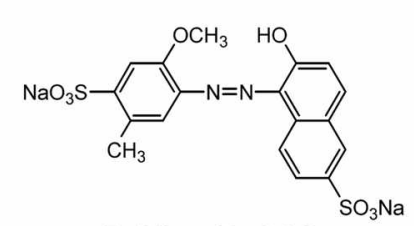

5, Allura Red AC

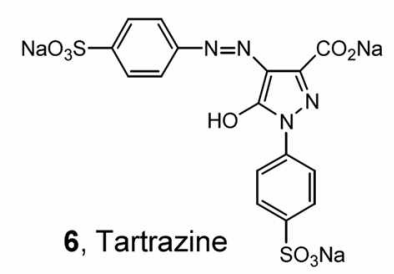

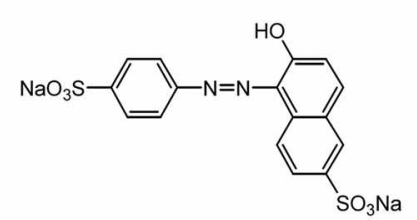

7, Sunset Yellow FCF

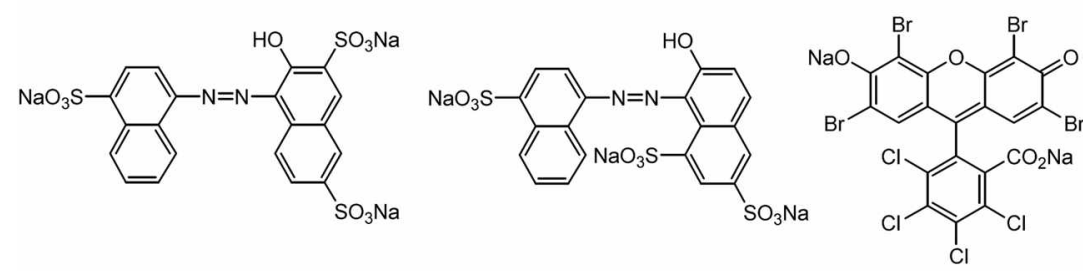

8, Amaranth

9, New Coccin

10, Phloxine B

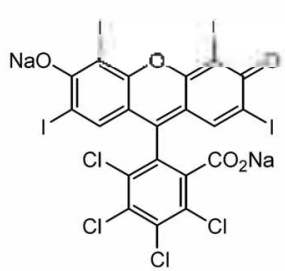

11, Rose Bengal

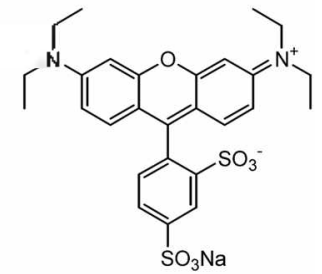

12, Acid Red 52

Figure 1. Chemical structure of synthetic food colorants permitted by the Food Sanitation Laws of U. S. A., European Union and/or Japan.<smiles>CCN(Cc1cccc(OS(=O)(=O)O)c1)c1ccc(C(c2ccc(N(C)C)cc2)c2ccc([N+](=O)[O-])cc2)cc1</smiles><smiles>CCN(CC)c1ccc(C(=C2C=CC(=O)C2)c2ccc(C)cc2[N+](=O)[O-])cc1</smiles>

14, Azure Blue VX

15, Brilliant Milling Green<smiles></smiles>

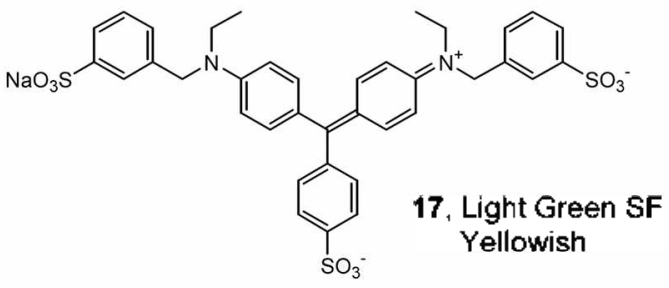<smiles>O=[N+]([O-])c1cc([N+](=O)[O-])c2ccccc2c1O</smiles>

18. Martius Yellow<smiles>O=[N+]([O-])c1ccc2c([N+](=O)[O-])cc([N+](=O)[O-])c([N+](=O)[O-])c2c1</smiles>

19. Naphthol Yellow S<smiles>Cc1cc(C)c(N=Nc2cc([N+](=O)[O-])c3ccccc3c2O)c([N+](=O)[O-])c1</smiles>

23. Ponceau SX

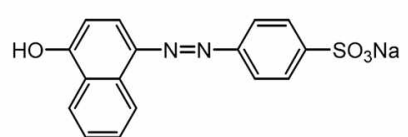

20, Orange 1

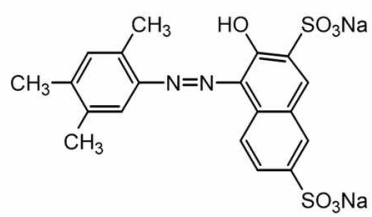

24, Ponceau R

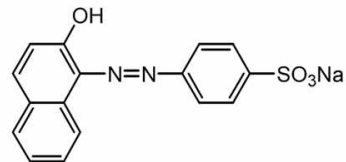

21, Orange 2

25. Eosine Yellowish

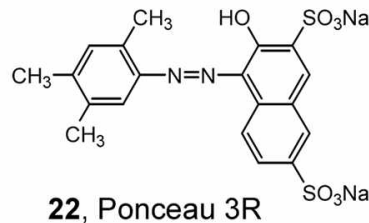<smiles></smiles>

26, Uranine

Figure 2. Chemical structure of food-forbidden colorants tested in this study. 
cellular phosphorylation level of proteins in collaboration with protein tyrosine kinases. ${ }^{17,18}$ Because PTPases play important roles as regulators of a diverse of signal transduction pathways, inhibition of PTPases by food colorants might disturb a certain signaling pathways resulting in adverse effects in human health. Therefore, we evaluated the inhibitory potency of the certified food colorants against PTPases (1-12, Table 1, Figure 1). Also examined were the dyes not allowed in food but they are structurally similar with the certified food colorants (13-26, Figure 2).

\section{Results and Discussion}

Concentrations of the colorants for half-maximal inhibition $\left(\mathrm{IC}_{\tilde{*}}\right)$ of the $p$-nitrophenyl phosphate $(p \mathrm{NPP})$ phosphohydrolase activity were measured against two human PTPases, PTP1B and TC-PTP, and a microbial PTPase YPTP1. ${ }^{15,19}$ As shown in Table 2, broad spectrum of $\mathrm{IC}_{\tilde{5} 0}$ values was observed both in food-permitted (1-12) and food-forbidden colorants (13-26). Although the colorants 13-26 are not

Table 2. Inhibition of PTPases by various synthetic dyes. Compounds 1-12 are permitted to add in foods in U. S. A. (1-7), Japan (1-3, 4-12) and/or E. U. (1, 2, 4-9). Compounds 13-26 are prohibited to be used in food

\begin{tabular}{|c|c|c|c|}
\hline \multirow{2}{*}{ Compounds - } & \multicolumn{3}{|c|}{$\mathrm{IC}_{50}(u \mathrm{M})^{u}$} \\
\hline & PTP1B & TC-PTP & YPTP1 \\
\hline 1 & $91 \pm 23$ & $>120$ & $>120$ \\
\hline 2 & $110 \pm 8$ & $85 \pm 11$ & $130 \pm 28$ \\
\hline 3 & $>124$ & $>120$ & $>120$ \\
\hline 4 & $6.0 \pm 0.6$ & $24 \pm 1$ & $13 \pm 2$ \\
\hline 5 & $33 \pm 6$ & $67 \pm 1$ & $410 \pm 80$ \\
\hline 6 & $>190$ & $>190$ & $>190$ \\
\hline 7 & $>220$ & $>220$ & $>220$ \\
\hline 8 & $34 \pm 7$ & $43 \pm 2$ & $103 \pm 15$ \\
\hline 9 & $>170$ & $>170$ & $>170$ \\
\hline 10 & $4.2 \pm 0.3$ & $14 \pm 1$ & $5.2 \pm 0.7$ \\
\hline 11 & $3.0 \pm 0.3$ & $4.0 \pm 0.2$ & $3.0 \pm 0.2$ \\
\hline 12 & $>170$ & $>170$ & $>170$ \\
\hline 13 & $8.0 \pm 0.6$ & $46 \pm 2$ & $16 \pm 2$ \\
\hline 14 & $>180$ & $>180$ & $>180$ \\
\hline 15 & $5.0 \pm 0.4$ & $27 \pm 4$ & $10 \pm 1$ \\
\hline 16 & $2.2 \pm 0.2$ & $9.0 \pm 0.3$ & $7.5 \pm 0.4$ \\
\hline 17 & $4.0 \pm 0.3$ & $9.0 \pm 0.3$ & $11 \pm 1$ \\
\hline 18 & $242 \pm 74$ & $>430$ & $>430$ \\
\hline 19 & $>280$ & $>280$ & $>280$ \\
\hline 20 & $47 \pm 4.5$ & $87 \pm 5$ & $76 \pm 7$ \\
\hline 21 & $134 \pm 24$ & $>290$ & $>290$ \\
\hline 22 & $60 \pm 8.3$ & $115 \pm 6$ & $69 \pm 13$ \\
\hline 23 & $>210$ & $>210$ & $>210$ \\
\hline 24 & $139 \pm 14$ & $>210$ & $68 \pm 6$ \\
\hline 25 & $63 \pm 6.8$ & $>140$ & $>140$ \\
\hline 26 & $>270$ & $>270$ & $>270$ \\
\hline
\end{tabular}

"TC $C_{\text {;n }}$ values were usually derived from duplicates or more of experiments using a range of inhibitor concentrations. The numbers indicate mean value \pm standard deviation allowed to be used in foods, most of them have FD\&C or $\mathrm{D} \& \mathrm{C}$ numbers indicating that they had previously been used in foods or they are currently used in drugs and/or cosmetic products. The dyes in this study could be classified arbitrarily into three groups - potent inhibitors $\left(\mathrm{IC}_{50}<10 \mu \mathrm{M}\right)$, medium potency inhibitors $\left(\mathrm{IC}_{50}=30-70 \mu \mathrm{M}\right)$ and poor inhibitors $\left(\mathrm{IC}_{50}>100 \mu \mathrm{M}\right)$. Diverse of colorants in this study can also be grouped according to the structural features; triphenylmethane dyes $(1,3,13-17)$, azo dyes $(5,6-$ $9,20-24)$, xanthene dye $(4,10-12,25,26)$ and others $(2,18$, 19) (Table 3). Food-permitted and food-forbidden colorants are evenly distributed in these structural groups. It is worth to note that the food dyes Erythrosine (4), Phloxine (10) and Rose Bengal (11) were potent inhibitors with $\mathrm{IC}_{50}$ values of $6.0 \mu \mathrm{M}, 4.2 \mu \mathrm{M}$ and $3.0 \mu \mathrm{M}$ respectively against PTPIB. Rose Bengal, the most potent among the three dyes, also strongly inhibited TC-PTP and YPTP1 with $\mathrm{IC}_{50}$ values of $4.0 \mu \mathrm{M}$ and $3.0 \mu \mathrm{M}$ respectively. The potent food inhibitors 4, 10 and 11 all belong to xanthene dyes compared to the potent food-forbidden dyes all of which belong to triphenylmethane dyes (Table 3 ).

As for the selectivity in the inhibition of the enzymes, the colorants exhibited less than four-fold differences in the $\mathbf{I C}_{50}$ values against the three PTPases. Exceptions were Allura Red AC (5) which exhibited 12-fold PTP1B selectivity against YPTP1 and Brilliant Milling Green (15) which exhibited 5.4-fold PTP1B selectivity against TC-PTP. The absence of discrimination between the PTPases might be understood on the basis of the structural similarity between the PTPases. ${ }^{20}$ Selective inhibition of a PTPase among dozens of PTPases present in human is a challenging hurdle in the development of a novel therapeutic agent targeting a certain PTPase - e.g. PTP1B inhibitor development for the treatment of type $\Pi$ diabetes. ${ }^{21}$

To investigate the mode of inhibition by the dyes, steadystate kinetic experiments of PTP1B and YPTP1 were performed for Indigo Carmine, Amaranth, Rose Bengal and Guinea green $\mathrm{B}$. They were the dyes with the lowest $\mathrm{IC}_{50}$ in each of the structural groups as classified in Table 3. The mode of inhibition was determined by the Lineweaver-Burk plot analysis of the results of the kinetic experiments (Figure 3). As shown in Table 4, Indigo Carmine and Amaranth inhibited both PTP1B and YPTP1 competitively indicating that they bind to the active site of the enzymes. Rose Bengal and Guinea green B were mixed type inhibitors of PTP1B

Table 3. Classification of synthetic dyes according to the chemical structure and the potency of PTTase Inhibition. Food colorants (112) are shown in italic

\begin{tabular}{lccc}
\hline Structural groups & Potent $^{2 \prime}$ & Medium $^{2}$ & Poor $^{\prime \prime}$ \\
\hline Triphenylmethane dye & $13,15-17$ & & $1,3,14$ \\
Azo dye & & $5,8,20,22$ & $6,7,9,21,23,24$ \\
Xanthene dye & $4,10,11$ & 25 & 12,26 \\
Others & & & $2,18,19$ \\
\hline
\end{tabular}

"Potency of PTPase inhibilion was arbitratily classified as potent $\left(\mathrm{IC}_{50}\right.$ ? $10 \mu \mathrm{M})$, medium $\left(\mathrm{IC}_{50}=30-70 \mu \mathrm{M}\right)$ and poor $\left(\mathrm{IC}_{50}>100 \mu \mathrm{M}\right)$. 
(a)

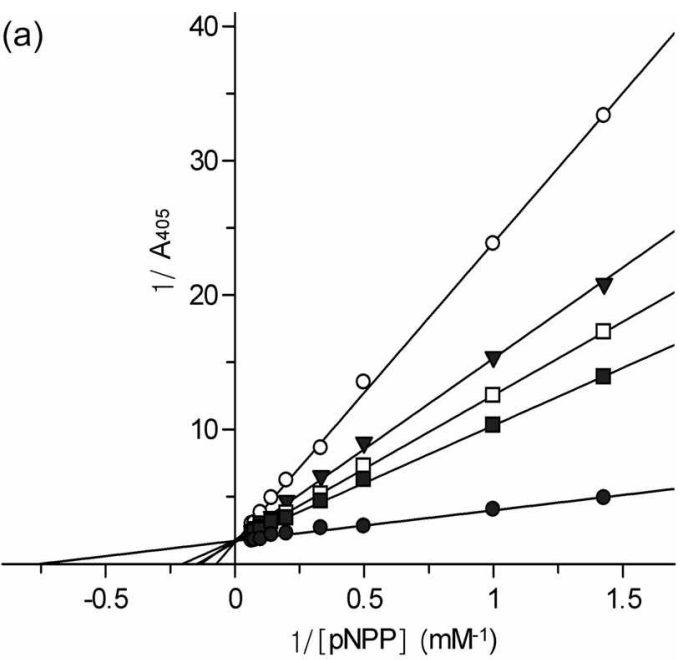

(b)
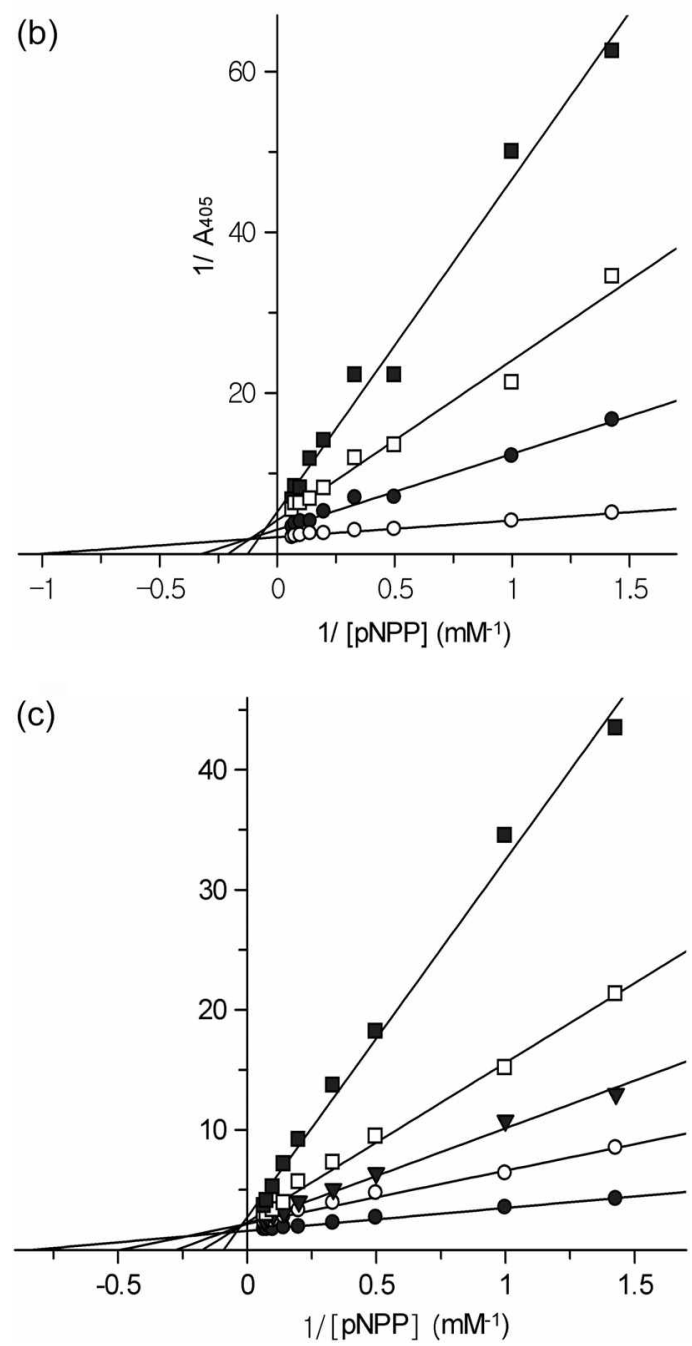

Figure 3. Lincweaver-Burk plot analysis. Phosphatase activity was measured against $p N P P$ in the presence of colorants. (a) PTP IB catalyzed reactions in the presence of $100 \mu \mathrm{M}(s), 60 \mu \mathrm{M}(\boldsymbol{\nabla}), 40$ $\mu \mathrm{M}(\square), 30 \mu \mathrm{M}$ ( $\mathbf{\square}$ ) or none ( $\bullet$ ) of Amaranth (8). (b) PTP $1 \mathrm{~B}$ catalyzed reactions in the presence of $20 \mu \mathrm{M}(\mathbf{\square}), 15 \mu \mathrm{M}(\square), 7$ $\mu \mathrm{M}$ ( ) or none ( $\mathbf{\square}$ ) or none ( $c$ ) of Rose Bengal (11). (c) YPTP1 catalyzed reactions in the presence of $12 \mu \mathrm{M}(\square), 10 \mu \mathrm{M}(\square), 8$ $\mu \mathrm{M}(\nabla), 6 \mu \mathrm{M}(0)$ or none $(\bullet)$ of Guinca Green B (16).
Table 4. Nature of TTTase Inhibition by the dyes representative of the structural groups

\begin{tabular}{cccc}
\hline \multirow{2}{*}{ Compounds } & \multirow{2}{*}{ Dyes $^{a}$} & \multicolumn{2}{c}{ Nature of Inhibition } \\
\cline { 3 - 4 } & & PTP1B & YPTP1 \\
\hline $\mathbf{2}$ & Indigo Carmine & Competitive & Competitive \\
$\mathbf{8}$ & Amaranth & Competitive & Competitive \\
$\mathbf{1 1}$ & Rose Bengal & Mixed & Competitive \\
$\mathbf{1 6}$ & Guinea green B & Mixed & Competitive \\
\hline
\end{tabular}

The dyes selected for the kinetic experiments were those with the lowest IC $\mathrm{C}_{\mathrm{s}}$ value in each of the structural groups as classified in Table 3.

but inhibited YPTP1 competitively. The fact that Rose Bengal and Guinea green $\mathrm{B}$ compete with the substrate for the binding on YPTP1 but not on PTP1B may reflect the possible interaction of the dyes with PTPIB on the second phosphate-binding site near the active site of PTP1B..$^{22}$ The second phosphate-binding site has been previously identified on PTP1B as a result of X-ray crystallographic study but the site was not present on YPTP1. Further structural study would explain the kinetic behavior of the dyes against the PTPases.

Although there are strict guidelines for chemicals to be approved as food additives, the safety of food colorants has not been rigorously proven and acceptable daily intake (ADI) has been used to minimize any possible unfavorable effect of the dyes. ${ }^{1}$ It is interesting to note that some of the food-forbidden dyes (for example, 13, 16, 17, 22, 23) in Figure 2 had previously been permitted for use in foods ${ }^{23}$ and they have FD\&C numbers. This fact might be extrapolated to predict that some of the currently food-permitted colorants could be forbidden sometime in the future when an unexpected toxic effect will be recognized for the dye. Considering the importance of PTPases in a diverse of cellular regulation, inhibition of those by some of the food colorants as observed in this study might initiate critical processes leading to adverse consequences on human health.

In summary, we investigated the inhibition of PTPases by certified food colorants as well as food-forbidden dyes. They inhibited the enzymes with a range of potencies. Noteworthy is that three of the food colorants inhibited the PTPases potently suggesting the possibility of harmful effects of the certified food colorants on human health.

\section{Experimental Section}

Reagents and Enzymes. All the dyes were purchased from TCI (Tokyo, Japan) as kits of food color testing solutions A (Catalog no. F 0118) and B (Catalog no. F 0119). The test solutions A included dyes permitted in Japan for use in foods (1-12, Fig. 1). The test solutions B included food-forbidden dyes (13-26, Fig. 2). Although the latter are currently not allowed in foods, most of them have FD\&C or $\mathrm{D} \& \mathrm{C}$ numbers. The dyes were used as received without further purification. PTPIB and YPTPI were expressed in $E$. coli expression systems and purified as described. ${ }^{15-19} \mathrm{TC}-$ PTP was purchased from New England Biolabs (Beverly, 
USA). The enzymes were diluted before use to an appropriate concentration by enzyme dilution buffer $(25 \mathrm{mM}$ Hepes, 5 mM EDTA, $1 \mathrm{mM}$ DTT, $1 \mathrm{mg} / \mathrm{mL}$ BSA, pH 7.3).

Enzyme Assay. For inhibition assay, inhibitor $(5 \mu \mathrm{L}$ in $\mathrm{H}_{2} \mathrm{O}$ ) was added to a mixture containing enzyme $(5 \mu \mathrm{L}), 5 \mathrm{x}$ reaction buffer ( $10 \mu \mathrm{L}, 0.5 \mathrm{M}$ Hepes, $25 \mathrm{mM}$ EDTA, $50 \mathrm{mM}$ DTT, $\mathrm{pH} 7.0$ ) and water $(25 \mu \mathrm{L})$ and it was incubated at 37 ${ }^{\circ} \mathrm{C}$ for $10 \mathrm{~min}$. The reaction was initiated by addition of $p$ nitrophenyl phosphate ( $p$ NPP) $(5 \mu \mathrm{L}, 20 \mathrm{mM})$ and, after 3 $\mathrm{min}$ at $37^{\circ} \mathrm{C}$, the reaction was quenched by addition of $\mathrm{NaOH}$ solution $(950 \mu \mathrm{L}, 0.5 \mathrm{M})$. The progress of the reaction was determined for the formation of $p$-nitrophenolate by measuring the absorbance at $405 \mathrm{~nm}$. The quantity of enzymes used for typical $50 \mu \mathrm{L}$ reaction was $200 \mathrm{ng}$ for PTP1B, $30 \mathrm{ng}$ for YPTP1 and 1.25 units (manufacturer's definition) for TC-PTP. The kinetic data were analyzed using GraFit 5.0 program.

Acknowledgements. This work was supported by the Grant from Inha University (2006). S. Shrestha and B. R. Bhattarai were recipients of BK21 fellowship.

\section{References}

1. Food and Dnig Administration/htemational Food Infonation Council Brochure; U. S. Food and Drug Administration: January 1993.

2. Naitoh, J.; Fox, B. M. Urology 1994, 44, 27 I.

3. Jeffords, D. L.; Lange, P. H.; DeWolf, W. C. Urology 1977, 9, 180.

4. Fairley, H. B. Ahesthesiology 1993, 79, 1454.
5. Borzelleca, J. F.; Goldenthal, E. I.; Wazeter, F. X.; Schardein, J. L. Food Chemical Toxicol 1987, 25,495.

6. Baldwin, J. L.; Chou, A. H.; Solomon, W. R. Amt. Allergy Asthma Intnitfol. 1997, 79, 415 .

7. Kuramolo, Y.; Yamada, K.; Lim, B. O.; Sugano, M. Biosci. Biotechnol. Biochem. 1997, 61, 723.

8. Yamada, J. J. Agric. Biol, Chem. 1991, 55, 1143.

9. Ashida, H.; Hashimoto, T.; Tsuji, S.; Kanazawa, K.; Danno, G.-I. J. Nitr. Sci. Vitaminol (Tokoo) $2000,46,130$.

10. van Hooft, J. A. Neurosc. Lett. 2002, 318, 163.

11. Stefanidou, M.; Alevisopoulos, G; Chatziloannou, A.; Koutselinis, A. Vet. Hum. Toxicol. 2003, 45, 103.

12. Tșuda, S.; Murakami, M.; Matsusaka, N.; Kano, K.; Taniguchi, K.; Sasaki, Y. F. Toxicol. Sci. 2001, 61, 92.

13. Yamazaki, H.; Nakami, H.; Yamaguchi, T. Nippon Shokthin Kagaku Gakkaishi 2002,9,89.

14. Worm, M.; Ehlers, I.; Sterry, W.; Zuberbier, T. Chin, Exp, Allemgy: 2000, 30, 407 .

15. Shrestha, S.; Shim, Y. S.; Kim, K. C.; Lee, K.-H.; Cho, H. Bioorg. Med. Chem. Lett. 2004, 14, 1923.

16. Cho, H.; Lee, D. Y.; Shrestha, S.; Shim. Y. S.; Kim, K. C. Kim, M.-K.; Lee, K.-H.; Won, J.; Kang, J.-S. Mol. Cells 2004, 18, 46.

17. Neel, B. G; Tonks, N. K. Cum, Opin. Cell Biol. 1997, 9, 193.

18. Ostuman, A.; Böhmer, F. D. Trends in Cell Biol. 2001, 11,258

19. Shrestha, S.; Lee, K.-H.; Cho, H. Bull. Korean Chem. Soc. 2004, 25,1303 .

20. Andersen, J. N.; Mortensen, O. H.; Peters, G H.; Drake, P. G.; Iversen, L. F.; Olsen, O. H.; Jansen, P. G; Andersen, H. S.; Tonks, N. K.; Møller, N. P. H. Mol. Cell. Biol, 2001, 21, 7II7.

21. Zhang, Z.-Y, Anm. Rev, Phom Toxicol. 2002, 42, 209.

22. Puis, Y. A.; Zhao, Y.; Sullivan, M.; Lawrence, D. S.; Almo, S. C.; Zhang. Z.-Y. Proc Natl. Acad. Sci. U.S.A. 1997, 94, 13420.

23. Hansen, W. H.; Long, E. L.; Davis, K. J.; Nelson, A. A.; Fitzhugh, O. G. Food Cosmet. Toxicol. 1966, 4, 389. 